\title{
DIE OPTREDE VAN DIE KOMMUNISTIESE MOONDHEDE MET BETREKKING TOT AFRIKA
}

\author{
Prof. J. II. Coetzee
}

\section{Inleidend: Drie tydperke}

Aanvanklik twee verduidelikende opmerkings oor die onderwerp. Die bewoording kommunistiese moondhede word met opset gebruik, soos later sal blyk, omdat dit m.i. om méer as ' $n$ blote optrede van en om die verbreiding van die kommunisme as ideologie gaan. Ter wille van 'n noodsaaklike beperking word die fokus hoofsaaklik gerig op die twee leidende kommunistiese moondhede, Rusland en China.

Ten einde die huidige optrede van hierdie state beter te kan begryp, trag ek om dit enigsins teen 'n historiese agtergrond tc stel. Dit mag hopelik perspektief gee op die veranderde taktiek en daardeur op die aanpasbaarheid van hulle strategie ten opsigte van nuwe omstandighede - 'n bewys van 'n uiterste realisme in politieke optrede, sy dit dan nie in ideologiese doelstelling nie.

Dit kom my voor asof die optrede van Rusland en China met betrekking tot Afrika in drie duidelik onderskeidbare fases besien kan word naamlik: Voor die Eerste Wêreldoorlog en die Bolsjewistiese rewolusie; van die Rooi-rewolusie van 1917 en die einde van die Eerste Wêreldoorlog tot na die einde van die Tweede Wêreldoorlog; en derdens die periode daarná.

In werklikheid het hierdie tydperk nie regstreekse betrekking op ons onderwerp nie. Uiteraard gaan dit voór 1917 nog geensins om kommunistiese moondhede of selfs 'n kommunistiese moondheid nie. Dit word net gedoen om aan te toon dat Afrika nie plotseling teen die twintigerjare van hierdie eeu die belangesfeer van Rusland en China binnegestap het nie.

China se kontakte met Afrika is veel ouer as dié van Rusland. Geografies is dit maklik verstaanbaar. Daar is aanduidings dat handel tussen China en die Afrikaanse ooskus, sy dit dan deur tussengangers, reeds in die sewende eeu aan die gang was. Teen die $10 \mathrm{e}$ eeu het Chinese geograwe reeds uitvoerige kennis besit van ' $\mathrm{n}$ land $\mathrm{Po} \mathrm{Pa} \mathrm{Li}$ aan die westelike see, heel waarskynlik 'n gebied aan die Somalikus. Vroeg in die $12 \mathrm{e}$ eeu het die meeste welgesteldes in Canton swart slawe 
besit terwyl ivoor, renosterhoring, skilpaddop en ambergrys en selfs goud in China bekend was as produkte van die land van die swart mense, naamlik Zanj.

Eers in die 15e eeu gedurende die regime van keiser YungLo, die derde uit die Ming-dinastie, is Chinese vlote na die Afrikaanse ooskus gestuur. Mogadishu, Brava en Juba is beskou as Chinese imperiale gebiede. Onder keiser Hsuan-Te het die keiserlike vloot in 1431-32 die Rooisee binnegevaar. Afgesien van voortgesette handel deur tussengangers - Arabiere, Indonesiërs, later Portugese en ander Europese seevaarders - het China vyf eeue lank geen verdere regstreekse belang in Afrika gehad nie.

Rusland was uiteraard geografies afgesny van Afrika. Gedurende die tweede helfte van die $19 \mathrm{e}$ eeu toe ander Europese moondhede hulle ingespan het om koloniale kleims in Afrika af te pen, is Rusland nog uitgesluit van dié wedloop deur sy geïsoleerde geografiese posisie. Origens het hy 'n groot koloniale hinterland in sy Asiatiese buurgebiede gehad. Rusland se deelname aan die protes teen Brittanje se voorwaarde van terugkeer na Egipte indien hy hom op daardie stadium sou onttrek (1887) was blykbaar meer gemotiveer deur belange noord van die Middellandse See as in Afrika self. Tog toon dit reeds dat gebeure noord en suid van die „ou wêreldsee" nie sonder onderlinge verband is nie.

Ongeveer hierdie tyd was Russiese ontdekkingsreisigers soos Junker ook in Afrika aanwesig, maar blykbaar in blote persoonlike hoedanigheid. Onder invloed van die Pan-Slavisme en met behulp van die Russies-ortodokse kerk het Rusland ongeveer dieselfde tyd nie-amptelik ook probeer om via Ethiopië 'n vastrapplek in Afrika te kry. Dit was egter sonder welslae.

Die geringe belangstelling in Afrika is tot op hierdie stadium gemotiveer deur handelsbelange enersyds - veral wat China betref - en deur nasionalies-politieke belange aan die ander kant. In geen geval was dit van besondere betekenis nie, behalwe vir soverre dit aantoon dat selfs met die relatief swak kommunikasiemiddels Afrika toentertyd reeds nie onbereikbaar was vir China nie, en dat die Europese en Afrikaanse kuste van die Middellandse See nie net deur die seewater verbind is nie maar ook aan politieke belange wat onder andere Rusland geraak het.

Die groot verandering wat na die einde van die Tweede 
Wêreldoorlog sou intree, was nie in die eerste plek 'n tegnologiese verbetering van kommunikasiemiddele nie. Dit lê in die politieke vergestalting van Marx en Engels se sosio-ekonomiese dogma: die nuwe totalitaristiese droom van 'n hemel op aarde wat dan ook die ganse aarde moes insluit. Die patroon wat dit aanneem, is aan $u$ bekend genoeg: die leer van die klassestryd, van gemeenskaplike besit van alle produksiemiddele en van geweldadige inskakeling van die ganse wêreld. „Werkers van die wốreld, verenig julle", was die slagspreuk.

Marx en sy medestanders se teorie was gegrond op 'n bepaalde siening van die gevolge van die industriële rewolusie soos dit in Europa verloop het. Dié siening het hulle op daardie stadium veralgemeen tot ' $n$ universele dogma. In die praktyk het dit min of meer die volgende doelstellinge en middele om die ideaal te bereik, ingehou. Die nywerheidswerkers is aan. vaar as die leër van die proletariaat wat verenig en opgelei moes word tot uitwissing van die kapitalistiese bourgeoisie. Dit moes ' $n$ wêreldrewolusie wees. In hierdie rewolusie en in die beoogde toestand sou daar geen plek wees vir nasionalisme of volksidentiteit nie - alles blote verdelingsmiddels bedink deur die kapitaliste. Die rewolusie sou buite Rusland bewerk word deur ideologiese toespitsing op die werkers en dus ook deur infiltrasie in en verowering van die vakbonde.

Die preokkupasie met die klassestryd het die aandag uiteraard gevestig op lande met ' $n$ industriële bevolking. Wat Afrika betref, was Suid-Afrika eintlik die enigste wat iets van Marx c.s. se uitgangspunt verteenwoordig het. Derhalwe is die kommunistiese rewolusionere optrede in Afrika hoofsaaklik op Suid-Afrika toegespits.

Die taktiek en strategie het op daardie stadium min of meer só daar uitgesien: Getrou aan die a- of anti-volkse en -nasionale grondslae van die Marxistiese dogma is gepoog om blanke en nie-blanke werkers saam te snoer tot die besef van 'n Suid-Afrikaanse proletariaat. Sprake van nie-blanke of blanke nasionalisme(s) mog daar nie wees nie - dit was trouens 'n doodsonde teen die kommunisme. Nieteenstaande welslae in die vakunies was hierdie mistasting van die kommuniste in Suid-Afrika waarskynlik die belangrikste rots waarop hulle ideologiese vordering gestrand het - tot ons voordeel.

Hierdie periode kan ongeveer soos volg opgesom word: Dit was 'n oorwegend ideologiese rewolusiepoging met die doel om 
'n wêreldwye Marxistiese gemeenskap daar te stel. Hoewel Rusland die prototipe en enigste amptelike staatsvesting van die Marxistiese dogma was, is daar nie bewustelik gedink aan 'n Russiese wêreldverowering nie. Dogmaties is alle nasionalisme en volksbewussyn beveg as strydig met die grondprinsipes van die internasionale of juister a-nasionale en a-volkse sosialisme. Die onderdrukte werkers moes georganiseer, opgelei en gelei word tot bevryding - nie onderdrukte en onvrye volke nie.

Die derde tydperk is voorberei deur die Tweede Wêreldoorlog en sy gevolge. Hierop moet nader ingegaan word. Dit kan getipeer word as die periode waarin die antinasionalisme in die kommunisme oorwin is deur die chauvinisme sonder dat die Marxistiese ideaal van 'n wêreldrewolusie verwerp is. Wesentlik word die sosialisme dan só gewysig dat dit nie langer 'n a-volkse, a-nasionale, wêreldomvattende mensheidstrewe na die verkryging van die sosialistiese sosio-ekonomies-politieke wêreldstaat is nie, maar 'n nasionaal-imperialistiese strewe van ' $n$ besondere volk, nasie en staat na wêreldoorheersing volgens die sosialistiese patroon. Met ander woorde, Rusland, of China of watter ander staat dit ook al mag wees, is nie 'n tocvallige histories-politieke prototipe van die begeerde sosialistiese wê. reldstaat nie, maar dit is Rusland of China se bewuste strewe om as kommunistiese Rusland of China die sosialistiese rewolusie voort te sit en te laat slaag. Dit is eensdeels die krag maar ook die swak plek in die nuwe benadering.

Takties en strategies is dit van besondere betekenis. Die beroep op die werkers kry 'n parallel in die geroep om uhuru. Die beroep op die onderdrukte volke om op te staan teen die imperialistiese en kolonialistiese oorheerser-onderdrukkers, word die eggo van die beroep op die proletariaat. Die woorde proletariaat, klassestryd, kapitaliste en bourgeoisie het sterk mededingers gekry in die woorde vryheidsvegters, nasionale vryheid, kolonialisme en imperialisme.

II. Doel en motivering van die kommunistiese moondhede in hulle optrede teenoor Afrika

Die feitlik onmiddellike ontstaan van twee teenoormekaarstaande geopolitiese wêreldblokke, in die algemeen en nie te noukeurig nie aangedui as die „vrye Weste" en die „kommunistiese Ooste", het dadelik ook die behoefte geskep an die soek na bondgenote en die verkryging van strategiese brug. 
hoofde van ekonomiese, militêre en politieke betekenis. Hierdie bondgenote kon alleen verkry word uit die „Derde Wèreld”, die sogenaamde neutralistiese of onverbonde lande van Afrika, Asië en Latyns-Amerika. Hoewel verspreid oor drie kontinente, het hierdie onverbondenes enkele gemeenskaplike eienskappe besit. Hulle was ,onderontwikkeld", het 'n korter of langer koloniale verlede gehad waaruit hulle besig was om ontvoog te word, hulle was besig om as nuwe state te ontplooi en het hierdie gebeure gesien as deel van die proses van dekolonisasie waardeur veral hulle buitelandse politiek gekleur sou word, en hulle was in mindere of meerdere mate emosioneel anti-Westers.

Op grond van hierdie gemeenskaplikhede het daar 'n soort losse verband ontstaan, veral wat die Afro-Asiatiese lande betref, versterk deur ' $n$ aantal konferensies en uitgedruk in die beleidsformule van neutralisme of onverbonclenheid - dus nie geassosieerde deel van een van die twee mededingende blokke nie maar met behoud van die vryheid om, volgens voorskrif van eie belang, op te tree volgens eie oordeel.

Alhoewel die kommuniste, net soos die Weste, die Derde Wêreld liewer uitgesproke aan hulle kant sou wou sien, het e.g. egter baie vroeg die gaping gewaar wat deur die neutralistiese beleid, teen die agtergrond van anti-kolonialisme, gelaat is en daarop toegeslaan. Stalin het gedurende die jare 19171921 reeds die aandag daarop gevestig dat dit die taak van die kommunisme was om die eeu-oue slaap van die volke in die Ooste te versteur en om die werkers en kleinboere te vervul met die bevrydende gees van die rewolusie, om hulle op te wek in die stryd teen imperialisme, en om laasgenoemde sy mees betroubare en onuitputlike agterhoede en reserwe te ontneem. Soos vroeër aangedui het die dogmatiese en Leninistiese en Stalinistiese benadering wesentlik berus op die Marxistiese Wes-Europese industriële benadering en het hulle nie heeltemal raad geweet met die Ooste nie, dit wil sê die hele onderontwikkelde wêreld, Afrika ingesluit.

Die wêreldtoestande na die Tweede Wêreldoorlog het Lenin se stelling weer skerp onder die aandag gebring, en dit was veral Kroestsjef wat geniaal daarin sou slaag om Lenin se oogmerk te versoen met 'n nuwe strategie. Doel en metode het besonder kompleks geword. Dit het lande soos Rusland met sy satelliete en later ook China gestel voor die eis om teenoor die vrye Westerse opponent die groots moontlike invloedsfeer 
te verkry. Ekonomies was dit onontbeerlik en politiek het dit veral belangrik geword deur die totstandkoming van die V.V.O. Maar agter die vredestydse mededinging staan die skimme van 'n moontlike militêre botsing; derhalwe moes dít eweneens, miskien veral, in gedagte gehou word. Want nieteenstaande alles wat gesê en gedoen word om oënskynlik vrede te bewaar, het die kommuniste die ideaal van die sosialistiese wêreldrewolusie nie laat vaar nie. Terwyl vreedsame koëksistensie luid verkondig word en die strategie ingrypend gewysig is, is die doel nie verander nie. Hierdie veelvuldige doelstellinge moet dus altyd in gedagte gehou word by ' $n$ poging tot ontleding van wat Rusland en China probeer om in Afrika en ander onontwikkelde lande te bereik.

Die metodes en middele wat deur die Kommunistiese blok aangewend word om sy oogmerke in Afrika te verwerklik, kan tot die volgende gereduseer word: welwillendheidskonferensies, leiersbesoeke oor en weer, hulp op die ekonomiese, tegniese, opvoedkundig-kulturele en militêre vlak en propaganda. Met enkele voorbeelde en opmerkings hieroor kan volstaan word.

Sedert 1955 was daar 'n feitlik onafgebroke reeks konferensies wat deur die betrokke kommunistiese leiersmoondhede gebruik is - dikwels in botsing met mekaar - om die welwillendheid van die Afro-Asiatiese state te verkry en te verstewig. Die eerste van die soort was die Delhi-konferensie (1955), waarop die Bandoeng-konferensie gevolg het, dan die Afro-Asiatiese Solidariteits-konferensie te Kairo (Des. 1957Jan. 1958), die Ekonomiese Konferensie en die Konferensie van Afro-Asiatiese Skrywers (1958); die Jeugkonferensie (Kairo, 1959): die tweede en derde solidariteitskonferensies (Conakry 1960 en Moshi 1963), die Sowjetse Afro-Asiatiese Solidariteitskonferensie (Stalinabad, 1960) ensovoorts. Die solidariteitskonferensies het byvoorbeeld uitgeloop op die daarstelling van elaborate bestuursliggame wat gereeld vergader en wat weer verdere konferensies, ook meer gespesialiseerdes soos dié vir ekonome, vir die jeug, vir skrywers, vir „vriende van die vrede" e.d.m. reël. Ten einde sy invloed en houvas op die soort konferensies te verstewig het die U.S.S.R. na die Stalinabadkonferensie sy eie Sowjet-solidariteitskomitee gestig met die besondere docl om die Sowjetpropaganda en die implementering van Sowjetbeleid op konferensies wat deur die Afro-Asiatiese Solidariteitskomitee georganiseer word, te bevorder. Want op laas- 
genoemde konferensies verloop dit gewoonlik só dat sterk Rus. siese en Chinese delegasies die besprekings probeer oorheers en hulle siening en beleid deur middel van mosies aanvaar probeer kry. Uiteraard word die permanente sekretariaat gefinansier deur die U.S.S.R. en Rooi China saam met enkele ander. Die Sowjetse komitee het hom verder bemoei met uitnodigings aan verskillende organisasies en persone uit Afrika en Asië na die Sowjet, stuur van verteenwoordigers na hierdie gebiede, organiseer van 'n "Afrika-week", en 'n „Algerynse week" in die U.S.S.R. by welke geleentheid in 19591.2 miljoen roebels ingesamel is ten bate van Algerië, aanbieding van beurse aan studente uit Afrika (60 beurse toegeken in 1960) en as medestigter van die Universiteit van Volkerevriendskap in Moskou.

Die tyd en plek van die konferensies, dic agenda, die besprekings en die resolusies word so beplan dat dit meteens ook 'n sterk propagandawaarde besit. Die Stalinabadkonferensie is byvoorbeeld in die Tadzhik S.S.R. belê om die Sowjet se Asiatiese karakter te beklemtoon teenoor die verwyte dat Rusland geen Asiatiese staat is of belange het nie. Die tyd is gekies om saam te val met Kroestsjef se voorstelle in die V.V. vir 'n wysiging van hierdie liggaam se struktuur en sy eise vir onmiddellike likwidasie van kolonialisme in Algerië en die Kongo. Die hele konferensie is oorheers deur hierdie voorstelle alhoewel die agenda slegs twee punte bevat het: Eerstens die stryd van die Afro-Asiatiese volke teen kolonialisme en imperialisme en tweedens die werk van die Sowjetkomitee vir Afro-Asiatiese Solidariteit. Die adjunk-sekretaris van die Sowjetkomitee het die doel van die konferensie só gestel: Die konferensie is belê op 'n tydstip wat al die volke van Asië en Afrika en die hele progressiewe mensheid warme ondersteuning verleen aan die verklaring ten gunste van die verlening van onafhanklikheid aan koloniale lande en volke deur die voorsitter van die Ministerraad van die U.S.S.R., Nikita Kroestsjef.

Dit is ' $n$ bekende feit dat die onverbonde state ekonomies onontwikkeld en arm is. Dit is net so bekend dat dit nie net noodsaaklik is dat hulle lewenspeil verhoog en hulle ekonomie op vaste voet geplaas moet word nie, maar dat dit by die leiers van hierdie volke feitlik 'n hartstog geword het om prestige te verkry deur ekonomiese vooruitgang. Daarvoor is hulp van buite onontbeerlik. Dat die „vrye Weste” ekonomies die 
beste daaraan toe is en dus veel beter toegerus is as die kommunistiese blok, is aan die onverbondenes ewe bekend en is by hulle, soos by die kommuniste, 'n doring in die vlees en 'n oorsaak van naywer. Die feit van hulle ekonomiese afhanklikheid van die Weste, meestal eensydig toegedig aan die kolonialisme as enigste oorsaak, is waarskynlik nog een van die remme aan 'n meer radikale linkse swaai.

Alhoewel die Rooi state geensins op gelyke voet kan meeding met die Weste wat betref ekonomiese hulpverlening aan die onverbonde onderontwikkelde state uit Afrika, Asië en Latyns-Amerika nie, het hulle tog die veld betree. Terwyl dit nie met eerlikheid beweer kan word dat die Westerse moondhede suiwer ekonomiese maatstawwe aanlê by sodanige hulpverlening nie maar die waarde van politieke diwidende laat meespreek, is die politicke en propagandistiese oorwegings by die Rooi lande verreweg die deurslaggewende. Hier staan die U.S.S.R. in 'n gunstiger posisie as China

Die sosialistiese ekonomiese stelsel skakel vanselfsprekend alle private kapitaalbelegging in die vorm van lenings, aandele, saakstigting of toekennings deur partikuliere stigtinge uit as hulpmiddele. Al wat res is staatstoekennings of hoogstens donasies deur staatsgeinisieerde en/of beheerde instansies in die vorm van beurse, strydfondse e.d.m. Die omvang van hierdie hulpverlening is nie presies bekend nie. Enkele van die regstreekse lenings uit die U.S.S.R. is een van 20 miljoen roebel aan die Soedan, terugbetaalbaar teen $2 \frac{1}{2}$ persent rente oor twaalf jaar; 400 miljoen roebel aan Ethiopië; 1,100 miljoen roebel aan die V.A.R. (uitgesonderd die vir die Aswandam). Hierdie lenings gaan vir 'n verskeidenheid doelstellinge: landbounavorsing en -ontwikkeling, metaal- en ander bedrywe, dam- en spoorwegkonstruksie, hidro-elektriese skemas, e.d.m. In hierdie opsig staan China ver agter by Rusland. Sy ekonomies-tegniese hulpverlening is hoofsaaklik beperk tot padaanleg en kleinere kredietverskaffing.

Die Sowjetunie lê veral klem op die betekenis van sy ekonomiese hulp aan die onderontwikkelde state. Daarmee bereik hy twee doeleindes. In die eerste plek blaas hy die relatief swak ekonomiese hulp op tot 'n geweldige begunstigende propaganda. In die tweede plek wen hy 'n tree of wat op sy mededinger China. Gedurende die afgelope anderhalf dekade het Sowjetpolitici dit oor en oor beklemtoon dat Afrika 
en nie Europa of Asië nie, die beslissende faktor sal wees in die stryd tussen die sosialistiese en kapitalistiese stelsels. Dit sal verseker word deur die omvangryke hulp wat Afrika ontvang van die „wêreldstelsel van sosialisme". So het Suslov beweer: Die stryders van die heroïese nasionale bevrydingsleër van Algerië, die gewapende magte van Indonesië, Yemen en ander lande weet goed wie se wapens hulle gehelp het in die stryd vir vryheid en onafhanklikheid teen die koloniseerders.

Sowjetteoretici beweer dat die stryd van die jong Afrikastate om ekonomiese onafhanklikheid ' $n$ pad is wat lei na 'n nuwe rewolusie waaruit 'n sosialistiese orde sal ontstaan en dat, afgesien van die vorm van nasionale sosialisme wat tans aanvaar word, hierdie state vroeër of later deur middel van Sowjethulp ware sosialisme sal bereik. Hiermee gaan saam die volgehoue Sowjetbeskuldigings dat die V.S.A., Brittanje en Frankryk, die ,imperialiste”, ,koloniseerders” en ,neo-kolonialiste", hulle dienste verleen in 'n poging om die verslawende orde te behou. Hulle sou dan poog om die Afrikavolke te oortuig dat die Sowjet probeer om die Afrika-vasteland met sy rykdomme te onderwerp aan die U.S.S.R. se invloed. Volgens Sowjetpropaganda is dit slegs hulp van die sosialistiese lande wat die nasionale ekonomie van die onderontwikkelde lande kan ontwikkel. „Die stryd vir die likwidasie van ekonomiese agterlikheid en die verkryging van die vinnigsmoontlike ekonomiese ontwikkeling in die vrygeworde lande is vandag die belangrikste vorm van die anti-imperialistiese stryd".

Uit die voorgaande is dit reeds duidelik dat die ekonomiese middel integraal verbind is aan die politieke doel. Dit blyk ook uit ander uitsprake. So het Prawda die volgende oor die Aswandam geskryf: „Die hoë dam styg bo die Nyl uit as 'n simbool van die herrysenis van die Egiptiese volk, 'n simbool van sy samewerking met die Sowjets... Die Aswandam, gebou met Sowjetkrediete en met die hulp van 'n leër van Sowjetingenieurs, sal vir altyd in die herinnering van die volke bly staan as 'n simbool van broederlike samewerking tussen die U.S.S.R. en die lande wat hulle vrygemaak het van die kolonialistiese juk". Uit hierdie en ander uitsprake blyk dit dat die projek, op die keper beskou, gesien word as 'n simboliese bruggehoof vir bestendiging van die Sowjet se invloedsfeer oor Afrika. Sowjethulp beoog stadige maar sekere ekonomiese dominasie, gevolg deur politieke oorheersing. Die groothartige hulp van die 
sosialistiese lande wat hulleself bevry, help om 'n einde te maak aan die idee van sosialisme en kommunisme en dit steun die vordering op weg na sosialisme.

Die regstreekse kapitaalverlening word origens aangevul deur handelsooreenkomste, ekonomiese advies, verskaffing van goedere, hulp met stadsbeplanning, hawebou en opbou van die infrastruktuur. Hierby sluit die verskaffing aan van tegnici en tegniese hulp vir groter projekte, hetsy in die landbou-, vervoer-, konstruksie- of nywerheidsektor. Dit is bekend hoe die Sowjet in hierdie verband hulp verleen aan die V.A.R. in verband met die bou van die Aswandam: kapitaal, planne, ingenieurs en tegnici, materiaal en vervoer. Duisende Sowjettegnici werk in Afrikalande aan nywerheids- en vervoerkonstruksie en aan geologiese opnames. Terwyl hierdie tegnici besig is met ter plaatse opleiding van inboorlinge, word van hulle verwag om hulle leerlinge met paslike Sowjetbeleid en kommunistiese leerstellinge te indoktrineer. Mits onthou word dat dit nie bloot Russiese of Chinese tegnici is nie, maar kommunistiese tegnici, blyk dit dat hiermee ook die veld van die propaganda, opvoeding en kultuur betree en 'n meer primêre doel as hulp aan onderontwikkeldes nagestreef word.

Welwillendheid teenoor die Rooi-lande word, net soos dit in die Westerse wêreld geskied, bevorder deur studiegeleenthede aan jong mense uit die Derde Wêreld te verskaf. Dit is begryplik dat Afrika en die ander onderontwikkelde lande groot behoefte aan tegnies, professioneel en akademies geskooldes het en dat van geleenthede vir sodanige studie, insluitende beurse, gretig gebruik gemaak sal word. Onder leiding van persone soos prof. Potekhin is ' $n$ nuwe dissipline naamlik Marxistiese Afrikastudies ontwikkel. Volgens 'n onlangse tweedelige Sowjetensiklopedie oor Afrika word deskundiges oor Afrika in die U.S.S.R. opgelei in geografie, ekonomie, geskiedenis, etnografie, letterkunde en Afrikatale. Die Sowjet heg groot waarde aan die opleiding van Afrikageleerdes ten einde Sowjet-vriendskap en -beleid in Afrika te bevorder. Die aanwesigheid van studente word aangevul deur besoekgeleenthede van leiers van kleiner en groter formaat of besoek van uitgesoekte verteenwoordigers van die kommunistiese kultuur aan die Afrikalande. Die hoogtepunt van sodanige welwillendheids besoeke is die ooprol van die rooi tapyt vir staatslui en ander potensieel belangrike persone op besoek agter die Rooi-gordyn. 
Verskillende leiers uit Afrikalande het hierdie kuur al ontvang: Nkrumah, Selassie, Nasser, Boumedienne, Kaunda en andere. Besonder tiperend van die gebruik wat van besoeke van staatsmanne oor-en-weer gemaak word, is die volgende gevalle.

China se pogings om die wêreldaandag in die algemeen en Afrika-aandag in die besonder op hom te trek, het byvoorbeeld geblyk uit premier Tsjou En-lai se Afrikabesoek van Desember 1963 tot Februarie 1964. Dit het tien Afrika- en drie Asiatiese state ingesluit. Alhoewel al tien die state ' $\mathrm{n}$ min of meer Kommunistiese vriendskaplike beleid gevolg het, was hulle tog uiters uiteenlopend: van Algerië met sy „volksrepubliek" tot die republieke van Guinee (betreklik Rooi-gesind) en Egipte (waarin die Kommunistiese Party verban is), die koninkryke Marokko en Ethiopië. Die doel was primêr diplomaties eerder as polities of ekonomies. Sy optrede en tocsprake het presies aangepas by die omstandighede, behoeftes en beleid van elke staat selfs tot die punt van verloëning van amptelike Chinese beleid. Nieteenstaande China se konflik met die Sowjet oor Kroestsjef se koëksistensiebeleid, verklaar Tsjou En-lai in Marokko: „Ons glo dit is moontlik dat lande met verskillende sosiale stelsels vreedsaam naasmekaar kan bestaan". In Tunisië gee hy die belofte om die vriendskap tussen die twee volke te versterk en om ekonomiese en personeel-uitruilings te bevorder. Dit bring hom wedersydse diplomatieke verteenwoordiging in die sak.

Deur 'n opportunisme te volg ver verwyder van Peking se origens rigide houding, het China waarskynlik heelwat simpatie in Afrika gewen, dit nieteenstaande Tanganyika, Kenya en Uganda nie baie in hulle skik was nie.

Tsjou En-lai se besoek het die onmiddellike reaksie gehad dat Kroestsjef, terwyl eersgenoemde nog in Egipte was, aangekondig het dat hy in die voorjaar Afrika gaan besoek. Dit sou saamval met die afsluiting van die Nyl by die Aswandam 'n besoek wat met groot fanfare aangekondig is. Diẻ besoek moes enersyds dien om die bande tussen Egipte en die U.S.S.R vaster te knoop en tweedens om verlore grond op China te herwin.

Toe Ethiopië in 1963 geprotesteer het teen die lewering van Sowjetwapens aan Somalië, het Moskou daarop geantwoord met 'n uitnodiging aan keiser Haile Selassie om die U.S.S.R. te besoek. Die vererende ontvangs moes dien om al die probleme uit te stryk. 


\section{Lokale rewolusionêre oorloë}

In aansluiting by die ekonomiese hulpverlening en by die aankweek van welwillendheid moet die militêre hulpverlening genoem word. Hierdie middel openbaar beter as enige van die vorige die doel en strategie van Rusland en China met betrekking tot Afrika, Asië en Latyns-Amerika.

Dit sluit immers nie net geld in vir die aankoop van wapens nie, maar die verskaffing van wapens self, opleiding van guerilla- en van gereëlde troepe, voorsiening van instrukteurs en selfs van offisiere. Boweal openbaar dit die geheel gewysigde Kommunistiese strategie met betrekking tot die onderontwikkelde wêreld in die verwekking van die sosialistiese wêreldrewolusie. Die gegewens oor Russiese, Chinese, Tsjeggiese en Oos-Duitse wapens in die hande van terroriste en rebelle, hetsy in Algerië, die Kongo, Somalië, Angola, Mosambiek of Rhodesië en die feite oor die opleiding van diegene wat hulle hanteer, is so bekend uit die pers en hofverslae dat verdere bespreking daaroor hier onnodig is. Dit sal profytliker wees om die aandag aan die rewolusionêre oorlog as strategie van die Rooi-state te wy.

Een van die belangrikste wysiginge wat Kroestsjef en sy volgelinge ingevoer het, was die aanpassing van die wêreldrewolusie by die veranderde toestande van ná die Tweede Wêreldoorlog. Terwyl Lenin verwag het dat plaaslike Kommunistiese aksies in onderskeie lande genoeg mag sal ontwikkel om die wêreldrewolusie teweeg te bring, het Stalin reeds geglo aan ' $n$ staande leër wat gebruik moes word in die eventuele botsing met die "imperialistiese" of "kapitalistiese" state ten einde die wôreldrewolusie te laat slaag.

Kroestsjef en sy aanhangers kom met 'n derde gedagte rustende op die voer van plaaslike oorloë en die vrees vir kernwapens. Die uitgangspunt was dat geeneen van die Westerse magte sy toevlug sou neem tot kernwapens in 'n plaaslike konflik nie, veral nie as dit gekamoefleer kan word as 'n burgeroorlog of ' $n$ nasionale bevrydingstryd nie. Die Sowjetbeleid sou derhalwe wees om die moontlikhede van 'n derde wêreld. oorlog soveel as moontlik te beperk, terwyl hy sou verseker dat die groots moontlike gebied in die greep gehou word van plaaslike ondermyningsoorloë sonder gevaar van 'n wêreldbrand. Dit sou geskied onder verkondiging van die leuse van vrede 
en koëksistensie. Die strategie vir die welslae van 'n wêreldrewolusie is verder bevorder deur die verwerping van die Lenin-Stalin-stelling van ,die noodwendigheid van oorlog in die imperialistiese fase" en die stel van die teorie van vreedsame rewolusie.

Vir die onmiddellike toepassing van die nuwe strategie het die twintigste partykongres besluit op die onderontwikkelde lande, waar die bevrydingsbeweging besonder gunstige omstandighede geskep het vir die voer van ondermyningsoorloë terwyl dié lande omgeskep kon word in magsvakume met moontlikhede van 'n derde wêreldoorlog in slegs enkele gevalle.

Die verwerping van grootskaalse oorlog en die aankondiging van vreedsame naasbestaan is gevolglik geen aanduiding van ' $n$ bereidheid om 'n versoening met die Weste te bewerkstellig nie, maar juis om die wêreldrewolusie te bevorder.

Sedert die Tweede Wêreldoorlog het die Kommuniste uitgebreide kennis oor die voer van ondermyningsoorloë opgedoen. In die Balkan (Yugoslawië, Albanië en Griekeland), in die Verre Ooste (China, Viëtnam, Maleia, Birma en Indonesië) en in die Nabye Ooste (Iran, Irak en Algerië), was daar voldoende geleentheid om, na geval, die verskillende soorte oorlogvoering waar te neem of aktief daarin deel te neem. Met die teorieë van Mao Tse-tung en die ervaringe van die Viëtminh, het dit geblyk moontlik te wees om die strategie en taktiek van hierdie tipe oorlog volmaak te ontwikkel.

'n Vergelyking van die verskillende rewolusionêre oorloë, dit wil sê oorloë om sosialistiese rewolusies teweeg te bring, sedert die Tweede Wêreldoorlog, bring sekere gemeenskaplike eienskappe aan die lig. Dit is in die eerste geval 'n stryd wat deur ' $n$ minderheid gevoer word ten einde algehele beheer te verkry oor 'n land of 'n gebied met die doel om die bestaande regime te vervang deur 'n kommunistiese diktatorskap. In hierdie proses word die beheer oor die bevolking geleidelik verkry deur 'n ingewikkelde gang van deels militêre deels politieke aard. Daarin word opstand en lokale oorlog, propaganda en ideologiese indringing, terroristiese bewind en organisasie gekombineer.

Die aard van die komplekse proses blyk uit die beginsels waarop die kommuniste besluit of in 'n land die voorvereistes aanwesig is om sodanige oorlog aan die gang te sit. Dit word voorafgegaan deur 'n ontleding van die algemene situasie, die 
relatiewe kragte aan weerskante en die algemene gewilligheid om te veg. Sodanige faktore sluit in die geopolitiese situasie, die sosiaal-ekonomiese struktuur, bevolkingsaanwas, getal, grootte en belangrikheid van sy stede, lewenstandaard, inkomste- en kapitaaldistribusie, toestand van etniese en godsdienstige minderhede, krag en swakhede van die bestaande orde, buitelandse betrekkinge en die algemene internasionale posisie, e.a. of intervensie te wagte is, van watter kant, in watter vorm, politiek, ekonomies of militêr.

Die tweede ontleding dek alle vrae met betrekking tot die werklike of potensiële beheer oor die bevolking: die graad van kontrole deur die huidige regering, die gesag van die howe, doeltreffendheid van die polisie, toestand van die weermag en die identiteit van almal wat die bestaande orde verteenwoordig of ondersteun. Dit sluit ook in die vatbaarheid van die bevolking vir rewolusionêre propaganda en die houding van alle partye teenoor die moontlikheid van 'n rewolusie. Die vraag na die algemene bereidheid om te veg vereis ' $n$ analise van die moreel van die weermag. Hieraan word besondere en afsonderlike aandag gegee.

Vir die Kommunis bestaan 'n rewolusionêre oorlog uit twee fases. Die eerste is die afbraak van die bestaande regime en die tweede die konstruktiewe vestiging van 'n nuwe orde. Die eerste sluit in alle aksies met die doel om die bestaande regime te infiltreer, te demoraliseer, en te disintegreer en om die fisieke likwidasie teweeg te bring van al sy verteenwoordigers en ondersteuners. Die metode is om 'n kloof te skep tussen die wettige administrasie en die bevolking en om die regering, politieke leiers en die leidende ondersteuners van mekaar te vervreem. Daarvoor moet die bestaande orde in diskrediet gebring word in die oë van die massa en van daardie ondersteuners wat vatbaar sou wees en om alle instellings behorende tot die regime, nl. polisie, leër, politieke partye ensovoorts te demoraliseer. Die geloof van regeerders en geregeerdes moet ondermyn word in die ideaal waarvoor die regime staan. Twyfel word opgewek in die etiese van amptelike beslissings en hofuitsprake; die politieke aspekte van hofsake word opgeblaas. Pogings word angewend om die regering tot wraakmaatreëls aan te spoor om sodoende ontevredenheid te verwek. Die doeltreffendheid van veiligheids- en beskermingsmaatreëls van regeringsweë word weerstaan. 
Van die doeltreffendste maatreëls is onverbloemde selektiewe en stelselmatige intimidasie. Eersgenoemde sluit in die verwydering van mense wie se kundigheid of gesag die bestaande orde steun; laasgenoemde behels sabotasie en intimidasie van ekonomiese, politieke of sosiale seksies van die samelewing deur die willekeurige verwydering van indiwiduele lede van die groepe. Die verwydering moet 'n skok in vreeseffek op die res uitoefen (moord op hoofmanne, sakemanne, amptenare). Dit geld ook die afbrand van huise, dood van vee of vernietiging van graan.

Wanneer dié stappe slaag, volg die fase van die guerillaoorlog. Die hoofdoel hiervan is nie soseer vernietiging van militêre personeel, konvooie of verdedigingspunte nie as om die militêre en polisie te treiter. Guerilla-oorlog moet 'n duursame toestand van onveiligheid skep.

Alles word in die skaal gegooi om die weifelaars en draadsitters te wen of om 'n wagtende houding in te neem. 'n Gewilde metode is om die revolusionêre oorlog aan te dien as ,'n regverdige oorlog ter wille van vryheid", ,'n nasionale bevrydingsoorlog”, ,afsku van die koloniale juk". Dit moet ten minste voorgestel word as 'n stryd wat spontaan uit die volk ontstaan het. Hierdie voorstelling moet veral buitelands geglo word.

Ten slotte vind die likwidasie van die oorblywende vestings van die ou orde plaas, selfs in die naam van 'n openlike oorlog. Elke geveg word gevolg deur eksekusies en grootskaalse deportasies.

\section{Fokus op Afrika}

Die vraag is nou: hoe is hierdie planne en beleide ten opsigte van Afrika geïmplementeer en waartoe het dit gelei? Ook in hierdie geval kan alleen 'n vlugtige oorsigtelike beeld gegee word, waarin die optrede van Rusland en China eintlik onderskei moet word.

Dit kom my voor asof Rusland aanvanklik, benewens sy doelstellinge in Suid-Afrika, probeer het om veral van die goeie gesindheid van Nkrumah en Sekou Toure gebruik te maak om ' $n$ brughoof op Ghana gevestig te kry. Dit mog die strategiese voordeel hê van verbindinge met Kuba en LatynsAmerika en terselfdertyd na die Kongo. Nkrumah se val het hieraan ' $n$ finale einde gebring. Geleidelik is die aandag ver- 
skuif na die V.A.R. en Algerië. Gebeure in Mei 1967 het aan Rusland die geleentheid gegee om 'n ou droom te verwesenlik, naamlik om sy vloot in die warm water van die Middellandse See te kry en Noord-Afrika van Egipte tot Algerië in 'n vooruitgeskowe Sowjetpos om te skep.

In Mei 1967 het Nasser 'n oormoedige aanval op Israel gewaag en verloor. Die situasie wat daardeur geskep is, is deur die Sowjet uitstekend tot sy voordeel benut. Die gevolg daarvan is dat die uitrusting en opleiding van die Egiptiese leër nou veel sterker in Russiese hande is as voorheen. Rusland se steun aan die Arabiese volke het hom die verwesenliking van sy ou-ou ideaal van aanwesigheid in die Middellandse See gebring. Daardeur beheer hy die Suezkanaal en derhalwe daardie toegang tot die Indiese Oseaan en die Ooskus van Afrika. Deur vir Boumedienne van Algerië die rooi tapyt oop te rol en Nasser in die skaduwee te stoot, is Algerië ook nader getrek na die Sowjet. Hoe lou die ander drie Noord-Afrikaanse state ook al mag staan teenoor die Sowjet, kan hulle voortaan nog minder as voorheen sy aanwesigheid ignoreer. Hierdeur is die U.S.S.R. besig om Noord-Afrika te beheer, en wie NoordAfrika beheer, beheer Wes-Europa. Meer nog: met die magsvakuum in die Indiese Oseaan, is Rusland se kanse besonder gunstig om hier in te tree en die Kaapse roete te bedreig.

Volgens Suslov bly dit vir die ware kommunis 'n onveranderlike waarheid dat die oorgang na sosialisme, oorgeset synde kommunistiese wêreldheerskappy, alleen moontlik is deur middel van 'n sosialistiese rewolusie en die diktatuur van die proletariaat. Daar val nie te redeneer oor ' $n$ rewolusie of nie, slegs oor die metodes. Want indien die kommunistiese partye alle hoop gaan vestig op 'n gewapende stryd ter uitsluiting van alle ander middele, ongeag die vraag of die massas bereid is om te veg, sal dit lei tot bitter neerlae. Die hoofdoel van die Sowjet se Afrikabeleid bly dus nog om die volke voor te berei vir hierdie stryd. Die belangrikste middel daartoe is die aanblaas van ekstreme nasionalisme en haat teen die Weste deur die verkondiging van die oorlog teen kolonialisme. Die skepping van ' $n$ nasionale ekonomie in Afrikalande en volle politieke onafhanklikheid sou alleen bereik kon word deur die pad van sosialistiese ontwikkeling in te slaan.

Hoeseer Sowjetvoorspellings oor die toekoms van Afrika in besonderhede mag verskil, bly die basiese beginsel daarvan 
nogtans die konsep van die sosialistiese rewolusie in elke Afrikaland. In die beleid van neutralisme en onverbondenheid gewaar die Sowjets die voortsetting van die anti-imperialistiese stryd onder nuwe historiese toestande: Neutralisme ,is die enigste weg wat die jong vredeliewende state in staat stel om doeltreffend saam te werk met sosialistiese lande terwyl hulle terselfdertyd streef na die likwidasie van die verslawende verhoudinge met die kapitalistiese lande".

Dit is waar dat die Sowjet se Afrikabeleid uit 'n Westerse standpunt aansienlike teenstrydighede vertoon betreffende onder andere die rol van Afrika-nasionalismes in die sosialisering van die kontinent, die stryd vir nasionale bevryding, die nasionaal-demokratiese rewolusie en die Arabiese eenheid. Die Sowjet sweep die nasionale en rassegevoel van die Arabiere op teen die Westerse kolonialiste, maar sodra hierdie gevoelens die Arabiere weglei van die Sowjetpatroon van "nasionale transformasie", word hulle beskuldig van „reaksionêre gevoele”, „rassisme" of „kleinburgerlike nasionalisme”. Wesentlik neem die Sowjets dus standpunt in teen die idee van „Negritude", die Afrika-karakter of -persoonlikheid en ander soortgelyke begrippe. Wat Ghana betref, word beweer dat die Ghanese sosioekonomiese hervorminge nie sosialisties en die Convention People's Party geen Marxisties-Leninistiese party is nie. Om die „nasionaal-demokratiese rewolusie” te volvoer moet Ghana sy regime (dié van Nkrumah) omverwerp en die sosialistiese pad volg.

Met die V.A.R. het die Sowjet ook probleme. Aan die een kant voorsien die U.S.S.R. Egipte met aansienlike ekonomiese, tegniese en militêre hulp in die hoop om Nasser se simpatie te behou in die stryd in Afrika teen die Westerse blok. Aan die ander kant kan hulle nie altyd hulle ontevredenheid verberg oor sy binnelandse beleid nie. Kroestsjef het hom in Egipte taamlik skerp uitgelaat oor die beklemtoning van eksklusiewe Arabiese nasionalisme. Skrywers wys onomwonde op die opvallende teenstrydigheid tussen belangrike ekonomiese veranderinge wat in die V.A.R. bewerkstellig is en die vaskleef van regerende kringe aan die ou ,reaksionêre ideologiese en politieke posisies".

Hoewel later op die toneel en ekonomies nie opgewasse teen Rusland nie, het oorbevolkte China ook nie hierdie onderbevolkte vasteland uit die oog verloor nie. Aanvanklik het Rooi 
China sy aandag ook hoofsaaklik gevestig op Guinee en KongoBrazzaville, hoewel die lande aan die ooskus vir hom eintlik bereikbaarder is. Hier tree China eers in met die totstandkoming van 'n "volksdemokrasie" in Zanzibar (1963) onder Chinese invloed. Die naam van Kao Liang word in hierdie verband genoem as inisieerder. Die vereniging van Tanganyika en Zanzibar tot die federasie van Tanzanië is opgevolg deur 'n watarskuwing deur Kenya, Uganda en Tanganyika aan daardie magte (blykbaar China) wat teen Afrika-eenheid werk. Nogtans kon pres. Nyerere tot nog toe nie daarin slaag om die Rooi Chinese uit Zanzibar en van die eiland Pemba verwyder te kry nie. En die verdere verloop hiervan is die nuwe vriendskap tussen Kaunda van Zambië en Peking. Die gevolg is nie alleen Chinese opleiding van terroriste in Dar-es-salaam vir aksie langs die Zambezi en die voorsiening van wapentuig en uitrusting nie. Hulle oorwegende aandeel in die bou van 'n pad en spoorweg tussen Dar-es-salaam en Lusaka hou veel belang. riker strategiese bedreiginge vir Suider-Afrika in as ekonomiese moontlikheid.

China se erns wat sy toetrede tot Afrika betref, blyk onder andere uit sy beleidsformuleringe in hierdie verband net na Tsjou En-lai se besoek: China ondersteun die Afrikavolke vir hulle stryd teen imperialisme, kolonialisme en neo-kolonialisme en vir die bereiking en handhawing van nasionale onafhanklikheid; China ondersteun die regerings van Afrikalande in hulle navolging van 'n beleid van vrede, neutralisme en ongebondenheid; ondersteun die Afrikavolke in hulle begeerte na solidariteit en eenheid in 'n vorm na hulle keuse; ondersteun die Afrikavolke in hulle pogings om hulle geskille te besleg deur vreedsame samesprekings; China se standpunt is dat die soewereiniteit van die Afrikastate gerespekteer moet word deur alle lande en dat enige oorskryding of inmenging teengestaan moet word. volke:

Dié beleid is aangevul deur een betreffende die Arabiese

Ondersteuning

in die stryd teen imperialisme vir nasionale vryheid;

vir ' $n$ beleid van vrede, neutraliteit en onverbondenheid; vir pogings tot verkryging van solidariteit en eenheid;

vir vreedsame beslegting van geskille; en

verwerping van vreemde inmenging. 


\section{Die Russies-Chinese wedloop}

'n Gemeenskaplike probleem vir Rusland en China is hulle konflik oor hierdie vasteland. In Prawda kla die Sowjet dat die Chinese kommunistiese leiers probeer om op alle moontlike maniere die Afro-Asiatiese volke te isoleer van die U.S.S.R. en laasgenoemde af te sny van die Arabiese lande. Die feit is dat die kommunistiese wêreldblok ten opsigte van bepaalde aspekte in twee mededingende blokke ontwikkel deur die opkoms van China wal reeds sy krag getoon het in konvensionele oorlog. voering in Uie Himalaya en in diversionêre rewolusionêre optrede in Laos, Vietnam en Zanzibar. Dit het reeds etlike bondgenoot-satelliete om hom versamel, naamlik Noord-Korea, Noord-Viëtnam en Albanië. Laasgenoemde is 'n geskikte brughoof vir deurvoering van sy Afrikabeleid. Vir die kommuniste hou dit die gevaar in van kragsverdeling in botsinge om nasionale belange en leierskap van die sosialistiese wêreld en vir die onderontwikkelde lande ' $n$ verdere keuse nieteenstaande hulle onverbondenheidsbeleid. Dit word al moeiliker om die V.S.A. en die U.S.S.R. teenoor mekaar af te speel sonder inagneming van China. Dit tref die onverbonde lande ook op ekonomiese gebied. Hulle het dringende behoefte aan handel en kredietverlening. China kan weinig hulp verleen. Hy kon weliswaar Albanië genoegsaam help om hom teenoor Moskou te skaar en gee blykbaar ook finansiële hulp aan Zanzibar, maar kan nie grootskaalse benodigde hulp aan groteres soos Egipte of Nigerië verleen nie. Ekonomies is China nog nie op weg nie. In 1960 en 1961 het dit nog geblyk dat die onderontwikkelde lande vyf keer soveel met mekaar verhandel het as met die hele SowjetChinese blok. In 1960 het hierdie blok slegs 3.6 persent van Latyns-Amerika, 6.2 persent van Afrika, 1.7 persent van Asië en 6.1 persent van Suid- en Suidoos-Asië se uitvoer geneem.

Die Sowjet-Chinese konflik en verskille oor die beleid wat onder andere ten opsigte van die onderontwikkelde lande gevolg word, lê weliswaar nie primér in die ekonomiese agterstand van China in vergelyking met Rusland nie, maar word daardeur ernstig geraak. Myns insiens moet die basiese oorsaak gesoek word in die inslag van die nasionalisme in die kommunisme van hierdie lande waaruit 'n Russiese kommunistiese teenoor 'n Chinese kommunistiese nasionalisme ontstaan soos dit ook waargeneem kon word in die geval van Yugoslawië, van Pole en vandag ook van Tsjeggo-Slowakye. 
Hierdie verskille het na vore gekom as 'n ideologiese botsing in geskrifte, op konferensies en op ander wyses. Een daarvan was die haastige Afrikareis van Kroestsjef nadat Tsjou En. lai sy toer deur Afrika voltooi het. Die konflik is egter aanhoudend en ten duidelikste weerspieël in die Afro-Asiatiese solidariteitsbeweging. Op die Kairo- en die Conakrykonferensie (resp. 1957 en 1960) het dit geblyk uit die pogings om die simpatieë van die Afrika- en Asiatiese lande te trek: die Sowjets deur beloftes van ekonomiese hulp en die Chinese deur hartroerende oproepe tot die stryd teen imperialisme en neokolonialisme. Openlike botsing was waarneembaar op die derde konferensie te Moshi (1963) en verderaan op vergaderinge van die Solidariteitsraad se Uitvoerende Komitee (Nicosia, September 1963) en op die Solidariteitsraad se vergadering te Algiers, 1964.

Die geskilpunte is hoofsaaklik die volgende:

vreedsame koëksistensie;

algemene ontwapening en dic Gedeeltelike Kerntoetsooreenkoms; en

die beslegting van grensgeskille op vreedsame wyse.

Die eintlike agtergrond en belangrikste wrywingsvlak was waarskynlik die Chinese beskuldiging dat die Sowjets selfsugtig optree in hulle ekonomiese hulpverlening aan die jong AfroAsiatiese State, terwyl die Sowjets daarop reageer deur die Chinese te beskuldig van rassisme en aanvalle op hulle nasionaliteitsbeleid in China.

Die vraagstuk van vreedsame naasbestaan is op die Nicosiavergadering te berde gebring. Die Chinese argument was dat hierdie beleid die sosialisme op 'n verkeerde spoor plaas deur af te sien van anti-imperialisme en rewolusie. „Dit verkondig die onsin dat die Afro-Asiatiese volke se taak om imperialisme en om 'n nuwe kolonialisme te bestry, beëindig is . . Die gevolg is dat die onderdrukte volke in ewigdurende verslawing moet leef". Hierin is China ondersteun deur afgevaardigdes uit Indonesië, Noord-Korea en Japan. Die Sowjets se antwoord by monde van Mirzo Tursun-Zade en ander, was dat in 'n wêreld wat verdeel staan tussen opponerende stelsels die enigste keuse lê tussen vreedsame naasbestaan en 'n wêreldkatastrofe. Die Sowjetresolusie in hierdie gees is aanvaar met 'n latere veelseggende kwalifikasie in Prawda: Vreedsame koëksistensie het alleen betrekking op interstaatlike verhoudings tussen lande 
met verskillende sosiale struktuur en onder geen omstandighede op antagonistiese klasse binne 'n land of tussen vreemde oorheersers en die onderdrukte volke nie... Die Sowjetblok verwerp versinsels te dien effekte dat die behoud van die beginsel van vreedsame naasbestaan soos dit deur Lenin verstaan en deur die Sowjet-Unie verdedig is, rekonsiliasie sou beteken tussen onderdruktes en onderdrukkers". Hiermee is die dubbelsinnige betekenis van die uitdrukking dan ook aan die kaak gestel.

Ewe heftig was die Chinese weerstand teen die beginsel van universele en totale ontwapening tesame met ondertekening van 'n verdrag om kerntoetse te beperk as 'n eerste stap in die rigting van ontwapening. Rusland se standpunt is gestel dat dit ' $n$ einde sal beteken van die geweldige gewapende magte en die huidige bewapening van die imperialistiese leërs wat deur hulle aangewend word teen die nasionale bevrydingsbeweging en tot inmenging in die sake van die jong soewereine state. Die Chinese het die kernverdrag beskryf as ,'n groot bedrog”. „Om die onderdrukte volke wys te maak dat die imperialiste hulle wapens sal afgee, hulle genadig sal wees en melk en heuning op 'n silwer-skinkbord sal aanbied, is nie net drome nie maar suiwere opium vir die volk". Ook die argument dat die middele wat deur ontwapening vrygestel word, tot voordeel van die onderontwikkelde volke sal kom, is betwyfel. Soos in die vorige geval het die Russe ook met hierdie standpunt die konferensies se ondersteuning verkry.

Kroestsjef se voorstel dat grensgeskille opgelos moes word op vreedsame wyse sonder geweld is heftig gekritiseer deur die Chinese afgevaardigdes (Algiers 1964). Hoewel Kroestsjef in sy voorstelle voorspraak gemaak het daarvoor dat die Amerikaners Taiwan moes ontruim aangesien dit 'n eeu-oue deel van China is, het die Chinese hom teengestaan. Volgens ' $n$ segsman sou die Chinese enige versoek aan die Afro-Asiatiese volke om onvoorwaardelik te kapituleer voor imperialistiese aggressors onder die bedrieglike leuse van vreedsame skikking, ten sterkste teenstaan. Die Sowjetleiers is daarby beskuldig van vertroebeling van geërfde grenskwessies. 'n Volk is geregtig om geweld te gebruik in die geval van besetting deur imperialiste: As voorbeelde is genoem Taiwan, Ogasawara, Okinawa, SuidViëtnam en Suid-Korea, Israel versus die Arabiere en die aanwesigheid van vreemde basisse in Afro-Asiatiese lande. Ter- 
selfdertyd redeneer die segsman dat territoriale geskille tussen Afro-Asiatiese lande onderling - die Sowjet uitgesluit vreedsaam geskik moes word.

Hierdie verskille - in woord en formulering eerder as in wese - staan in verband met die twee state se toestande. Die U.S.S.R. kon hom, na sy omvangryke anneksasies gedurende en net na die oorlog, die weelde veroorloof om tydelik afsydig te staan van verdere inlywinge. China staan aan die beginpunt van sy ekspansionisme (Tibet en Indië) en weier om sy grensaansprake sonder geweld op te los. Hoe inkonsekwent en deur eiebelang belaai die strydpunt is, blyk verder daaruit dat Rusland tog geweld as 'n metode van skikking aanvaar byvoorbeeld deur wapens aan Somalië te verskaf om sy aansprake op grondgebied in Kenya, Ethiopië en Frans-Somaliland af te dwing net soos aan Indonesië in sy aansprake op Maleisiese gebied. Verder raak dit ook U.S.S.R. en Chinese grensgeskille. Terwyl China eise stel ten opsigte van bepaalde Sowjetgebiede, kom die Sowjetleiers met teenbeskuldigings dat China herhaaldelik die gemeenskaplike grens oortree. Dit word duidelik dat elkeen se stelling propagandisties is met die doel om ' $n$ magsbeleid te bedek. Eenkant is dit die beleid van 'n staat wie se hebsug tydelik bevredig is; aan die ander kant dié van 'n staat wie se landhonger nog gestil moet word. Kroestsjef se boodskap is ' $n$ blote beroep op state om nie toevlug te neem tot geweld vir die verandering van bestaande grense nie, sonder om iets te sê oor die U.S.S.R. se grensuitbreiding tussen 1939 en 1945.

Ten tyde van die Algiers-vergadering van die Solidariteitsraad, het die Chinese delegasie die verskil in ekonomiese hulp aan Afro-Asiatiese lande van die kant van Rusland en van China opgehaal. Hier is Rusland openlik beskuldig van die sondes wat voorheen alleen aan imperialiste en kolonialiste toegeskryf is. Die Sowjets sou, soos die V.S.A., Brittanje en Frankryk, die bestaande verslawende toestande behou deur hulle dienste aan die Afro-Asiate aan te bied. Hy sou by sodanige hulp die houding van 'n grootmag-chauvinisme en nasionale egoisme aanslaan tot skade van die ekonomiese en politieke belange van die ontvangers en tot oneer van die naam van die sosialistiese lande.

Die redes vir China se beskuldigings moet gesoek word in sy onvermoë om op gelyke voet met die U.S.S.R. mee te ding. 
Uit vrees om prestige te verloor in die oë van die Afro-Asiatiese lande, neem China sy toevlug tot verdenkingsaaiery teen Rusland. Die Russiese hulp het die Chinese aanbiedinge net so ver oortref as wat Moskou se beloftes van hulp op die verskillende konferensies Peking se rewolusionêre slagkrete oorskadu het. In Nepal byvoorbeeld het die Sowjet 'n spoorweg van 120 kilometer gebou, tot verbetering van sy invloed in hierdie gebied wat China uiters graag aan sy kant wou hê, te meer omdat China van aldrie sy vroeër beloofde projekte in Nepal ('n pad van Katmandu na Lhasa, 'n sement- en papierfabriek) moes afstand doen weens kapitaalgebrek. In Indonesië en Somalië gebeur dieselfde. In laasgenoemde bou Rusland ' $n$ hawe en gee hy verdere substansiële hulp, terwyl China hom moet beperk tot die bou van 'n kort stukkie pad en dic verleen van beperkte krediet.

Die praktiese onmoontlikheid om met die U.S.S.R. mee te ding op hierdie terrein, het China gedwing om 'n ander weg in te slaan, naamlik om in sy propaganda ten opsigte van Chinese en Sowjetse ekonomiese hulp laasgenoemde af te kam en sy eie te prys. Op sy Afrikatoer het Tsjou En-lai in Ghana agt beginsels van Chinese ekonomiese hulpverlening geformuleer sonder om ooit Russiese en Chinese hulp te vergelyk. Terwyl Sowjet-propaganda wat tot die Afro-Asiate gerig word baie aandag gee aan die belangrikheid om die ekonomie van hierdie lande te konsolideer, gee Chinese leiers hulle eerste aandag aan die beweerde belangrikheid van die rewolusionêre stryd teen imperialisme. Die Sowjet sê: „Die stryd vir die likwidasie van ekonomiese agterlikheid en die versekering van die vinnigsmoontlike ekonomiese ontwikkeling in die bevryde lande is vandag die belangrikste vorm van die stryd teen imperialis me”. Daarteenoor beweer die Chinese: „'n Bepaalde buitemag argumenteer dat die eerste en sentrale taak van die nuwe opkomende lande in suiwer ekonomiese rekonstruksie bestaan Hierdie foutiewe argument trag in werklikheid om die AfroAsiatiese volke se huidige taak om imperialisme en ou en nuwe kolonialisme te beveg af te skryf en om "die pad te open vir ekonomiese aggressie deur kolonialisme".

Eintlik neem die Chinese 'n vyfde wapen ter hand om die invloedsfeer van die Sowjets in Afrika en Asië ten minste te beperk. Die vraag word gestel of die Sowjet 'n aandeel mag hê in die Afro-Asiatiese beweging. Dit geskied op grond van 
die bewering dat die U.S.S.R. nie 'n Asiatiese moondheid is nie. In reaksie beskuldig die Sowjetleiers die Chinese van rassisme, chauvinisme en nasionale onverdraagsaamheid. China se eis dat die U.S.S.R. uitgesluit behoort te word van „die anti-imperialistiese front" van die Afro-Asiatiese lande word gebaseer op sy „drie kontinente"-teorie. Daarvolgens het die fokuspunt van die stryd teen imperialisme uitbeweeg uit die vlak van die verhoudinge tussen imperialisme enersyds en die kamp van die Afro-Asiatiese en sosialistiese lande andersyds na die vlak van die verhoudinge tussen imperialisme en die nasionale bevrydingsbeweging, sodat slegs Afrika, Asië en Latyns-Amerika vandag die belangrikste krag van die wêreldrewolusie vorm. Die beslissende rol vir hierdic rewolusie sal derhalwe slegs deur hierdie drie kontinente gespeel word in die stryd van nasionale bevryding teen imperialisme en nie deur die hulp van non-Asiatiese lande in die sosialistiese kamp nie.

Dit behoort hieruit duidelik te wees dat daar ideologies en in uiteindelike doeistelling, naamlik die sosialistiese wêreldrewolusie, weinig indien enige verskil tussen China en die Sowjet-Unie bestaan. Die geskille ontspruit uit die begeerte by albei om beheer te verkry oor die rewolusionêre en nasionale bevrydingsbewegings in Afrika en elders. Die beklemtoning geskied om propagandistiese redes. Op hierdie stadium hou dit weinig troos in dat dit deur ' $n$ botsing die krag van een of albei gaan verswak wat Afrika betref. Dit lyk eerder asof die onderlinge konflik albei stimuleer om die aanslag op Afrika meer verbete voort te sit: Rusland openlik op ekonomiese vlak en meer bedektelik op die gebied van die rewolusionêre lokale bevrydingsoorlog, en China radikaal en ewe verbete openlik op ideologiese en militêre gebied. Hoe relatief min Afrika tot dusver van die Marxistiese leerstellinge uit Moskou in Peking geleer het - en ek meen dat daar veel minder werklike ideologiese Marxisme onder die Afrikavolke bestaan as kwasi-sosialistiese nabootsings en simptome van bondgenootskaplike simpatieë - die feit kan nie ontken word nie dat die Russiese en Chinese kommunistiese strategie van die guerillastryd en die terreur Afrika tot erfenis geword het. In die paring van terreur met radikale nasionalistiese hartstog en in die ondersteuning daarvan deur propaganda, opleiding, algemene ondersteuning en wapentuig, lê die gevaar uit hierdie oorde vir die orde in Afrika vandag. Die tekens is duidelik te 
lees, ook dié van subtiele oorwinnings. In Viëtnam is die V.S.A. nie bereid om die Vietcong as vryheidsvegters te beskryf nie maar as guerillas. Maar in Afrika, oral aan die Zambezi, word dieselfde soort gewapendes van Moskou en Peking, oor Londen en Washington as vryheidsvegters bestempel.

\section{ENKELE BRONNE VIR VERDERE RAADPLEGING:}

Behr, Edward: The Algerian problem; Penguin, 1961

Brzezinski, Z. (ed.): Africa and the Communist world; Stanford, 1963 Harrigan, Anthony: Red star over Africa; Kaapstad, 1964.

Horrabin, J. F.: An atlas of Africa; Praeger, N.Y., 1960.

Laqueur, Walter Z.: Communism and Nationalism in Tropical Africa

In: Quigg (ed.): Africa; Praeger, N.Y., 1964.

Lessing, Pieter: Africa's red harvest; London, 1962.

Mansfield, Peter: Nasser's Egypt; Penguin, 1965.

Martin, Laurence W. (ed.): Neutralism and nonalignment; Praeger, N.Y., 1963.

Oliver, Roland and Fage, J. D.: A short history of Africa; Penguin, 1962 Oliver, R. T. and Mathew, G.: History of East Africa I; Oxford, 1963.

S.A.U.K.: Ons Vasteland, Afrika.

\section{TYYDSKRIFTE:}

Bulletin van die Afrika-Instituut: Julie 1964, September 1965, Januarie 1966, April 1966, Augustus 1966, Augustus 1967, Januarie 1968.

Internationale Spectator: 22 Mei 1967.

News Check: 9 Februarie 1965, 26 Februarie 1965, 18 Junie 1965, 31 Desember 1965, 29 Desember 1967, 9 Februarie 1968.

\section{AFRIKA-SEMINARE (P.U. VIR C.H.O.):}

Coetzee, J. H.: Die Kommunistiese Moondhede en Afrika; Sept. 1961. Coetzee, J. H.: Noord-Afrika - aktualiteit in die konflik tussen die Ooste en Weste; Maart 1968.

INSTITUTE FOR STUDY OF THE U.S.S.R:

1. (Bulletin).

Kashin, A.: The Soviet and Chinese paths to Communism; Vol. VIII, no. 5; Mei 1861.

Kashin, A.: Chinese military doctrine; Vol. VIII, no. 11, November 1960 Marin, Y.: Soviet Policy in Africa; Vol. XI, no. 6; June, 1964.

Mian-Dhin'am: The results of Chau En-lai's visit to Africa; Vol. XI no. 7; July, 1964

Stieger, Martin: The nature of Soviet colonialism; Vol. VIII, no. 5; May, 1861.

Stolte, Stefan C.: The underdeveloped countries between two blocs: Vol. XI, no. 7; July, 1864. 
Stolte, Stefan C.: Africa between two power blocks; Vol. VIII, no. 5; May, 1961.

Von Stackelberg, Georg A.: Afro-Asian Solidarity and the Sino-Soviet dispute; Vol. XI, no. 8; Aug., 1964.

Von Stackelberg, Georg A.: Soviet Afro-Asian policy enters a new stage; Vol. VII, no. 11; Nov., 1960.

Von Stackelberg, Georg A.: Soviet African studies as a weapon of Soviet policy; Vol. VII, no. 9; Sept., 1960

2. ANALYSIS OF CURRENT DEVELOPMENTS IN THE SOVIET UNION:

Albert, Valery M.: Soviet policy in Latin America; No. 314; 14 Apr. 1964

Kashin, Aleksandr. A.: The Sino-Soviet conflict and the second AfroAsian Conference; No. 369; 22 June 1965.

STUDIES ON THE SOVIET UNION:

Agarwala, Pran Nath: Communist exploration of facilities in developing countries; No. II, 4; 1963

Avtorkhanov, A. G.: The underdeveloped countries in the Soviet impire; No. IV, 4; 1965.

Fedenko, Panas: Liberation abroad and colonialism at home; No. IV, 4; 1965.

Von Stackelberg, Georg A.: The aims of Soviet research in Asia and Africa; No. JI, 2; 1962.

ENCYCLOPAEDIA BRITANNICA EN BRITANNICA BOOK OF THIS YEAR 1964-1968:

Artikels onder die volgende hoofde met tersake onderafdelings:

Africa: (aspekte met betrekking tot kommunisme, China en U.S.S.R.).

China: (aspekte met betrekking tot Afrika, U.S.S.R., propaganda).

Communist movement (met betrekking tot Afrikalande, U.S.S.R., China). U.S.S.R.: (met betrekking tot Afrika, Midde-Ooste, China, propaganda, hulpverlening).

NUUS OOR AFRIKA:

Nommer van 13 Junie 1967.

Nommer van 4 Maart 1968.

AFRICA STUDIES ASSOCIATION MEETING, N.Y., 1967:

(Ongepubliseerde referate):

Legassick, Martin: The consequences of African guerilla activity for South Africa's relations with her neighbours.

McGowan, Patrick J.: Factors and correlations in African foreign policy. 